\title{
Construction of the Quality Evaluation System of Chinese-Foreign Cooperative Program
}

\author{
Haiying Ma ${ }^{1, a^{*}}$ and Yajian Sun ${ }^{2, b}$ \\ ${ }^{1,2}$ School of Economics, Northwest Minzu University, Lanzhou (730124), P.R.China \\ axmahaiying8888@163.com, ${ }^{\mathrm{a}}$ 760336805@qq.com
}

Keywords: Chinese-foreign ooperative program; Teaching Evaluation; Quality; Cconstruction

\begin{abstract}
With international perspective in the OECD and UNESCO and American Baldrige AUQA education quality prize and Australia research, building the Chinese-foreign cooperation program project quality evaluation system in colleges and universities is classified: types, characteristics, teaching staff, teaching management and quality, school funds and facilities and social recognition and so on six secondary indicators and 26 tertiary indicators. For Chinese-foreign cooperation program to establish the system of the project quality assessment provides a scientific judgment, cooperation program project internal self-evaluation in colleges and universities promote the sustainable development, and subsequent government education departments of Chinese-foreign cooperation program project evaluation practice has strong theoretical guiding significance.
\end{abstract}

\section{Introduction}

In the economic globalization and internationalization of higher Education practice, the Chinese-foreign cooperation program is developing rapidly in recent years as new education mode, it not only increased the supply of Education, promote the university teaching reform and disciplines construction, at the same time meet the diversified needs of the public schooling, promote the diversification of the personnel training mode and teaching conditions improved, has increased the diversity and selectivity of the higher Education supply. But there is no denying the fact that the Chinese and foreign cooperation program in the process of development in recent years, also met with some difficulties, one of the important reason is that our country has not established effective Chinese-foreign cooperation program in colleges and universities of quality assurance and evaluation system. Professor Bi jiaju of Tongji University proposed that Chinese-foreign cooperative program should also accept quality assessment. China's accession to the WTO and make a commitment to open education means the further opening of education market in China, especially the higher education market.

\section{Research Progress on the Influence Factors of Education on Cross-border Education}

Research Status of International Organizations. In November 2003, the OECD (Organization for Economic Cooperation and Development) with the Norwegian ministry of Education jointly held the second international Education service trade on the BBS, Cross-border Education (Transnational Education) as a new concept of common global recognition. UNESCO and the OECD have organized several groups of experts to convene meetings on the quality of cross-border education. In 2004, UNESCO launched a global international quality assurance and accreditation BBS, in November 2004, UNESCO and the OECD jointly drafted a cross-border provide higher education quality assurance outline. However, there is not yet an internationally accepted post-secondary education certification and quality assurance system. In 1987, the OECD in all aspects of the environment more mature conditions, start the study of Education development Indicators, the results of the study are embodied in the Education overview: the OECD Indicators, the book is the OECD's center for Education research and reform since 1991, introduced the important publications on a regular basis. 


\section{Research on the Quality Evaluation of Education in the United States and Australia}

The Malcolm Baldrige National Education Quality Award in the United States. The Baldrige Criteria for Performance Excellence is based on the assessment of the education quality award in the American country. Award outstanding performance evaluation criteria in the field of education proposed the core values and concepts which form the basis of education standards, the core values and concepts for any nature. The scale of education organization is one of the key elements for success, and associated with the most basic needs of students. The education quality award of the United States and the standard of performance excellence education are mainly embodied in the following core values and concepts.

There are seven categories of performance excellence education standards, including 19 projects, each with specific areas including 33 areas. In order to maintain the advanced nature of education quality prize to help education organization to deal with increasingly complex dynamic environment, focusing on strategic drive performance, the selection criteria and indicators system of America's national education quality prize every year in a timely manner.

Table 1 US education quality award criteria and distribution (2006 edition)

\begin{tabular}{|c|c|c|c|c|c|}
\hline Category & Project/Item & Field & Value & & Weight \\
\hline \multirow{5}{*}{ Leadship } & \multirow[b]{2}{*}{ Senior leadership } & Vision and values & & \multirow{5}{*}{120} & \multirow{5}{*}{$12 \%$} \\
\hline & & $\begin{array}{l}\text { Communication and organizational } \\
\text { performance }\end{array}$ & 70 & & \\
\hline & \multirow{3}{*}{$\begin{array}{l}\text { Management } \quad \text { social } \\
\text { responsibility }\end{array}$} & Organization and management & & & \\
\hline & & Legal and moral behavior & 50 & & \\
\hline & & Support for major social groups & & & \\
\hline \multirow{4}{*}{$\begin{array}{l}\text { Strategic } \\
\text { planning }\end{array}$} & \multirow{2}{*}{ Strategic development } & The process of strategic development & 40 & \multirow{4}{*}{85} & \multirow{4}{*}{$8.50 \%$} \\
\hline & & strategic target & 40 & & \\
\hline & \multirow{2}{*}{$\begin{array}{ll}\text { University } & \text { strategic } \\
\text { deployment } & \end{array}$} & Plan of action deployment & & & \\
\hline & & Performance planning & 45 & & \\
\hline \multirow{3}{*}{$\begin{array}{l}\text { Students, } \\
\text { stakeholders, } \\
\text { and market } \\
\text { centers }\end{array}$} & $\begin{array}{l}\text { Students, } \\
\text { knowledge }\end{array}$ & $\begin{array}{l}\text { Students, stakeholders, and market } \\
\text { knowledge }\end{array}$ & 40 & \multirow{3}{*}{85} & \multirow{3}{*}{$8.50 \%$} \\
\hline & Student, & Establish relationships with students, people & & & \\
\hline & $\begin{array}{l}\text { relationship } \\
\text { satisfaction }\end{array}$ & $\begin{array}{l}\text { Student and related person satisfaction } \\
\text { measurement }\end{array}$ & 45 & & \\
\hline \multirow{5}{*}{$\begin{array}{l}\text { Measurement, } \\
\text { analysis and } \\
\text { knowledge } \\
\text { management }\end{array}$} & \multirow{2}{*}{$\begin{array}{l}\text { measurement, analysis, } \\
\text { review of organizational } \\
\text { performance }\end{array}$} & Performance measurement & \multirow[b]{2}{*}{45} & \multirow{5}{*}{90} & \multirow{5}{*}{$9 \%$} \\
\hline & & Performance analysis and review & & & \\
\hline & \multirow{3}{*}{$\begin{array}{l}\text { Information, knowledge } \\
\text { management }\end{array}$} & Availability of data and information & \multirow{3}{*}{45} & & \\
\hline & & Organizational knowledge management & & & \\
\hline & & $\begin{array}{l}\text { The quality of data, information and } \\
\text { knowledge }\end{array}$ & & & \\
\hline \multirow{7}{*}{$\begin{array}{l}\text { Teachers, staff } \\
\text { centers }\end{array}$} & \multirow{3}{*}{ Working system } & $\begin{array}{l}\text { Organization and management of the work } \\
\text { process }\end{array}$ & & \multirow{7}{*}{85} & \multirow{7}{*}{$8.50 \%$} \\
\hline & & Staff performance management system & 35 & & \\
\hline & & $\begin{array}{l}\text { Teachers' employment and professional } \\
\text { development }\end{array}$ & & & \\
\hline & \multirow{2}{*}{$\begin{array}{l}\text { Employee learning, } \\
\text { motivation }\end{array}$} & Educational training and development of staff & \multirow{2}{*}{25} & & \\
\hline & & Motivations and professional development & & & \\
\hline & \multirow{2}{*}{$\begin{array}{l}\text { Employees welfare, } \\
\text { satisfaction }\end{array}$} & work environment & \multirow{2}{*}{25} & & \\
\hline & & Support, satisfaction to the teachers and staff & & & \\
\hline \multirow{2}{*}{$\begin{array}{l}\text { Process } \\
\text { management }\end{array}$} & $\begin{array}{l}\text { The process of Learning } \\
\text { Center }\end{array}$ & Support process for the Learning Center & 45 & & \\
\hline & $\begin{array}{l}\text { Support process } \\
\text { operation planning }\end{array}$ & $\begin{array}{l}\text { Financial resources, emergency operation } \\
\text { planning }\end{array}$ & 40 & 85 & $8.50 \%$ \\
\hline & Students' learning results & & 100 & & \\
\hline & Results of the attention of & udents, related people & 70 & & \\
\hline $\begin{array}{l}\text { School } \\
\text { nerformance }\end{array}$ & Budgetary, financial and $\mathrm{m}$ & rket results & 70 & 450 & $45 \%$ \\
\hline performance & Employee results & & 70 & 450 & $45 \%$ \\
\hline & Results of the effectivenes & of school organization & 0 & & \\
\hline & Results of leadership and s & cial responsibility & 70 & & \\
\hline TOTAL & & & & 1000 & $100 \%$ \\
\hline
\end{tabular}


Research progress of Australian University Quality Agency. Australian education quality guarantee system has been gradually establish in the $1950 \mathrm{~s}$, the education quality guarantee system is the integration of five by the federal government, state governments, namely AUQA, Australian qualification certification evaluation agency and university of five parts. In April 2000, the Australia government department of education and training of youth sponsored Australia to set up an independent non-profit institutions-Australian universities quality department. Quality Audit and Assurance for Transnational Education published in 2006, describes a cross-border Education Quality evaluation method for Australian universities with 17 evaluation indicators.

\section{The Construction Principle of the Quality Evaluation System}

The Systematic Principle. Chinese-foreign cooperation program project quality evaluation system is involving cooperative program type, teaching management and quality, social recognition of complex structure system has strong integrity, therefore in the setup of evaluation index system, systematic evaluation index should be considered.

The Principle of Combination of Qualitative and Quantitative. The indicator system should be set with quantitative indexes whenever possible. However in practice in the development of Sino-foreign cooperation program project, involving a variety of social, institutional and environmental factors of variable, in many of these variables is difficult to quantify, or even impossible to quantify to evaluate the quality of Chinese-foreign cooperation program.

The Principle of Completeness. Completeness means that the information of the evaluation index system is both necessary and sufficient. It is a complete group of indicators composed of several indicators. In theory, more than one index will cause the overlap and waste of information, and the lack of one index will result in insufficient information.

The Principle of Comparability. The evaluation index system is used to evaluate the evaluation index system. It is often used to analyze the vertical (Dynamic) and horizontal (Static) analysis, to compare the various objects of evaluation, or to evaluate a particular object dynamically. In order to make the evaluation results comparable, indicators must be selected with the same base and has a certain significance, and drawn from the evaluation objects and important common properties.

\section{Establishment of Quality Evaluation Index System}

The Establishment of the Index System. Based on the above elaboration, quality of Chinese-foreign cooperation program project research should fully draw lessons from American Baldrige wave prize of outstanding performance evaluation criteria, the Australian AUQA evaluation model and the reference of the domestic research results of many scholars. The factors that affect the quality of cooperative education are multifaceted and should be used to evaluate the quality of the main evaluation indexes as far as possible.

Establishment of Indicators: Type of Schooling. The establishment of the school type is more concerned with the application of the index system. Because of cooperation program project evaluation cannot be divorced from reality, not from attributes to take on the cooperation program project itself of different types of the response about the quality of the project itself is different.

Establishment of Indicators: Social Recognition. It is a practice to evaluate the social benefits of education, to put the reputation of the school and the success rate of graduates in important position. The Chinese-foreign cooperatively-run project in China should be oriented by market demand, and highlight the social benefits of cooperative education. Social acceptance is based on the above considerations.

Set up Indicators: School Characteristics. To develop and standardize Chinese-foreign cooperative program, the core is to introduce high-quality education resources. This is also the biggest difference between Chinese-foreign cooperative program and ordinary schools. In addition, the partners foreign countries choice, the concept of running a school and training goals and programmers are also different. Therefore, the index system should establish the characteristics of the school. 
Evaluation System Framework. Wave award in the United States, according to the above elaboration, Baldrige outstanding performance evaluation criteria, evaluation model of Australia AUQA, domestic Tan and Yan's research results and research, this paper construct the Chinese-foreign cooperation program project quality evaluation system framework (see Table 2)

Table 2 The framework of the quality evaluation system for Chinese-foreign cooperative program

\begin{tabular}{|c|c|c|}
\hline $\begin{array}{l}\text { First level } \\
\text { index }\end{array}$ & Second level index & Indicator description \\
\hline \multirow{4}{*}{$\begin{array}{l}\text { Type of school } \\
\text { running }\end{array}$} & Culture level & Graduate student, \\
\hline & The scale of school running & $\begin{array}{l}\text { The number of students in schools in the past three } \\
\text { years }\end{array}$ \\
\hline & Educational type & Education, non education or training \\
\hline & $\begin{array}{l}\text { The geographical position of } \\
\text { running project }\end{array}$ & Beijing, Shanghai, Western Region \\
\hline \multirow{5}{*}{$\begin{array}{l}\text { Characteristic } \\
\text { of running a } \\
\text { school }\end{array}$} & Training goals and programs & The goal is clear and the training program is feasible \\
\hline & The influence of the University & Badly needed, irreplaceable, potential influence, etc. \\
\hline & $\begin{array}{l}\text { The idea of running a school is } \\
\text { unique }\end{array}$ & Advanced, planning strategy is scientific and feasible \\
\hline & $\begin{array}{l}\text { Introduction of high quality } \\
\text { education resources }\end{array}$ & High quality education resources in foreign countries \\
\hline & Partner's choice & Selection of partners \\
\hline \multirow{5}{*}{ Teachers' status } & The composition of teachers & Proportion of nationality, foreign teachers and experts \\
\hline & Teacher's educational structure & Proportion of teachers with doctorate degree \\
\hline & Proportion of full-time teachers & $\begin{array}{l}\text { Proportion of the total number of teachers and staff } \\
\text { members }\end{array}$ \\
\hline & Academic support & $\begin{array}{l}\text { Academic atmosphere, special lecture, scientific } \\
\text { research }\end{array}$ \\
\hline & $\begin{array}{l}\text { Foreign teachers' recognition of } \\
\text { Chinese culture }\end{array}$ & $\begin{array}{l}\text { respect and love Chinese culture and satisfied with the } \\
\text { works }\end{array}$ \\
\hline \multirow{6}{*}{$\begin{array}{l}\text { Teaching } \\
\text { management } \\
\text { and quality }\end{array}$} & Form of teaching organization & Teaching plan, syllabus and teaching method \\
\hline & Enrolment method & Planned and out of plan enrolment \\
\hline & Teaching monitoring & Student satisfaction, teaching monitoring \\
\hline & Introduction of teaching materials & $\begin{array}{l}\text { Introduction of foreign textbooks, digestion or } \\
\text { adaptation }\end{array}$ \\
\hline & Dissertation & certain academic value and practical value \\
\hline & Students' language ability & IELTS or TOEFL, English proficiency certification \\
\hline \multirow{4}{*}{$\begin{array}{l}\text { Funds and } \\
\text { facilities for } \\
\text { running } \\
\text { schools }\end{array}$} & Tuition income & Annual average tuition, the proportion of tuition fees \\
\hline & Financial management status & $\begin{array}{l}\text { The source structure and operation status of running } \\
\text { funds }\end{array}$ \\
\hline & $\begin{array}{l}\text { Teaching and experimental } \\
\text { facilities }\end{array}$ & Teaching, equipment, multimedia, teaching guarantee \\
\hline & Environment for running a school & School buildings, books, and international environment \\
\hline \multirow{5}{*}{$\begin{array}{l}\text { Social } \\
\text { accreditation }\end{array}$} & Evaluation of students and parents & applying for the employment rate the job position \\
\hline & $\begin{array}{l}\text { Employment rate and employment } \\
\text { position }\end{array}$ & Employment rate, salary treatment \\
\hline & Enterprise unit feedback & The adaptability, comprehensive quality and team spirit \\
\hline & Local government approval & $\begin{array}{l}\text { Government approval support, influence on local } \\
\text { society }\end{array}$ \\
\hline & $\begin{array}{l}\text { local non-governmental } \\
\text { organizations }\end{array}$ & The support of a major community, institution \\
\hline
\end{tabular}




\section{Conclusions and Suggestions}

Robert S.K. Aplan and David P. Norton of the United States have said no measurement, no management. In the management practice of Chinese-foreign cooperative program, it can also be considered that without evaluation, it cannot be managed. Based on the research of education quality prize and Australia, put forward the influence of the key factors on the quality of the Chinese-foreign cooperation program project in colleges and universities is respectively: types, characteristics, teaching staff, teaching management and quality, school funds and facilities and social recognition and so on six secondary indicators and 26 tertiary indicators.

\section{Acknowledgements}

This work was supported by the Pilot joint program of comprehensive professional reform of International Economics and Trade (Joint Program, USU and NWUN) (Grant No:2017XJZYZHGGSD-01) and by Research joint program on education and teaching reform (Grant No:2017XJJG-12) of the Northwest Minzu University.

\section{References}

[1] Wan Dan, Market opening: the quality assurance of import high education service in China, Modern education science: High Education Research, 10(2012)22-26.

[2] Tan xiangming, Preliminary evaluation of Sino-foreign cooperative education in Shanghai, China Higher Education Evaluation, 3 (2004) 48-53.

[3] Xu Qin, Factors influencing the quality of Chinese-foreign cooperative education and analysis of countermeasures, Comparison of Education Research, 10 (2008)105-107.

[4] Yin Yongjian, Guo Wei, Quality evaluation of Chinese-foreign cooperative program in Shaanxi province, Journal of Xi 'an Engineering University, 3 (2009) 107-113.

[5] Wang Guoqiang, Discussion on the application of satisfaction evaluation of college students, China Quality, 12 (2002) 54-64.

[6] Zhao Guojie, Preliminary study on the expectation quality of education in university college, Journal of Northwest Agricultural Science and Technology, 2(2003)89-97.

[7] Chang Yaping, Study on the evaluation system and evaluation model of college students in Chinese universities, Research on Higher Education, 9 (2007) 82-87.

[8] Fang bao jun, Analysis of influencing factors of undergraduate teaching quality in engineering undergraduates, Higher Education Research, 6 (2010)78-83. 